\section{Time trends in prostate cancer mortality according to major geographic regions of Brazil: an analysis of three decades}

\author{
Tendência temporal da mortalidade por câncer \\ de próstata segundo macrorregiões do Brasil: \\ uma análise de três décadas
}

\author{
Las tendencias de la mortalidad por cáncer de \\ próstata a través del tiempo, según las diferentes \\ regiones brasileñas: un análisis de tres décadas
}

Mara Beatriz Martins Conceição 1,2 Antonio Fernando Boing 1

Karen Glazer Peres 1,3
1 Centro de Ciências da Saúde, Universidade Federal de Santa Catarina, Florianópolis, Brasil.

2 Secretaria de Estado da Saúde de Santa Catarina Florianópolis, Brasil. 3 School of Dentistry, The University of Adelaide, Adelaide, Australia.

Correspondence M. B. M. Conceição Programa de Pós-graduação em Saúde Coletiva, Centro de Ciências da Saúde. Universidade Federal de Santa Catarina.

Rua Capitão Romualdo de Barros 694, Bloco B, apto. 503, Florianópolis, SC 88040-600, Brasil. marabmc@yahoo.com.br

\begin{abstract}
The aim of this study was to analyze prostate cancer mortality and time trends in Brazil, according to major geographic regions, States, and age brackets. Data on deaths from 1980 to 2010 were obtained from the Mortality Information System. Mortality trends were estimated using Prais-Winsten generalized linear regression. An upward time trend was observed in mortality in all regions of Brazil, with a mean annual increase of 2.8\%. The upward trend in mortality occurred in most of the age brackets, with a concentration of deaths in men 70 to 79 years of age $(41 \%)$ and a significant increase in the 40 to 60-year age bracket. The mortality rate increased significantly in all age brackets in the Northeast, compared to the other regions of Brazil. The study highlighted the importance of redistributing deaths from ill-defined causes in order to correct the mortality rates. The results point to significant regional differences and the need for continuous monitoring of mortality from prostate cancer in Brazil.
\end{abstract}

Prostatic Neoplasms; Mortality; Men's Health

\section{Resumo}

Analisar a distribuição e a tendência temporal da mortalidade por câncer de próstata segundo macrorregiões, Unidades Federativas (UF) $e$ faixa etária no Brasil. Foram utilizados dados do Sistema de Informações sobre Mortalidade (SIM), dos óbitos ocorridos entre 1980 e 2010. Estimou-se a tendência de mortalidade pelo método de Prais-Winsten de regressão linear generalizada. Verificou-se tendência temporal ascendente na taxa de mortalidade em todas as regiões do país, com aumento médio de 2,8\% ao ano. A tendência ascendente na taxa de mortalidade ocorreu na maioria das faixas etárias, com concentração de óbitos entre homens de 70 a 79 anos (41\%) e aumento significativo entre 40 e 60 anos. Houve um aumento significativo na taxa de mortalidade da Região Nordeste, e nas $25 \mathrm{UF}$ em todas as faixas etárias comparada às demais regiões do Brasil. Verificou-se a importância na redistribuição de óbitos por causas mal definidas para correção das taxas de mortalidade. Os resultados apontam diferenças significativas regionais e a necessidade de monitoramento contínuo da mortalidade por câncer de próstata no Brasil.

Neoplasias da Próstata; Mortalidade; Saúde do Homem 


\section{Introduction}

Prostate cancer is the second leading tumor in incidence and the sixth cause of death among men in the world 1. In Brazil, in the two years 2012 and 2013 there were approximately 60,180 new cases of prostate cancer, or an estimated risk of 62 new cases per 100,000 men, ranking first among cancers in men, excluding skin cancer 2 . In 20 years, the crude mortality rate increased from 3.7 deaths (1979) to 8.9 deaths per 100,000 (1990), ranking second as cause of death from cancer among men since $1999{ }^{3}$. The economic cost of detecting, treating, and monitoring prostate cancer is high, due to the aggregate costs, burdening the health system and individual patients and contributing to the families' impoverishment 4 . In the United States, in 2008, expenditures were nearly US\$ 110,520 per patient 5 .

Prostate cancer raises serious challenges for the development of preventive measures, given the lack of knowledge on its natural history, in addition to presenting a prolonged latency period with multifocal and heterogeneous characteristics 6 .

The only well-established risk factor for prostate cancer is age. Approximately $62 \%$ of cases in the world occur in men 65 years or older ${ }^{2}$. In the United States, prostate cancer incidence increased from 13.6 cases per 100,000 to 59.8 per 100,000 in men under 65 years, and from 649.3 to 763.4 cases per 100,000 in men over 65 years from 1975 to 2010 7. This difference has been attributed to the increase in screening with digital rectal examination and prostate-specific antigen (PSA) screening in men 50 years and older 8.

Prostate cancer in individuals with a positive family history represents $13 \%$ to $26 \%$ of all cases. Epidemiological studies highlight that the risk of developing the disease among individuals with a family history is two to three times greater than expected for men of the same age bracket and ethnic group without a family history. Clinically, familial prostate cancer syndromes are diagnosed in $43 \%$ of patients less 70 years of age and $9 \%$ of those over 85 years 9 .

Research also suggests that race or ethnicity is a risk factor for the disease, in addition to geographic region. Among African-descendant men in the United States, Jamaica, and other Caribbean countries, the risk of prostate cancer is $60 \%$ greater when compared to white Americans, while for Asian-American men the risk is $38 \%$ lower ${ }^{9}$. This difference has been attributed to genetic susceptibility ( $5 \%$ to $10 \%$ ) but also to heterogeneity in access to health services and different lifestyles between these groups. Diets with high animal fat and low intake of vitamins D and E, selenium, and isoflavonoids have been associated with increased risk of developing prostate cancer 2,6.

Mortality rates from prostate cancer have decreased since 1990 in economically developed countries of North America and Europe and later in countries such as Chile, Argentina, Cuba, and Uruguay. Although this decline has been attributed to expansion in screening with PSA 10 , there is no evidence of benefit from this measure for the majority of men without symptoms of the disease 11,12 .

Studies in Brazil since the 1980s point to an upward trend in the mortality rate from prostate cancer 13,14,15. The South and Southeast, the wealthiest and most economically developed regions of the country, show a higher share of deaths from cancer when compared to the North and Northeast 13,15. In Recife, capital of Pernambuco State in Northeast Brazil, Oliveira Jr. \& Cesse 16 showed that although prostate was the second most common cancer site among men, since the risk was concentrated in the over-50 age bracket, its impact on years of potential life lost (YPLL) was the second lowest in 1990 and the lowest in 1999 (with a $24.6 \%$ drop in that decade), suggesting that deaths from prostate cancer were occurring at older ages.

Few studies in Brazil have analyzed mortality trends from prostate cancer. Secondary mortality data are available with $100 \%$ coverage and high national scope, thus allowing evaluations of trends in the disease itself and in health services' case-resolution capacity. However, there are important gaps in knowledge on differences in health services access, use, and performance, besides cultural and socioeconomic characteristics related to lifestyle. These aspects appear to be reflected in annual variations in mortality rates from prostate cancer, with significant differences between the country's major geographic regions in the last 31 years of coverage of the national Mortality Information System.

A literature review on prostate cancer mortality trends in PubMed, SciELO, and LILACS from June 2002 to June 2012 showed that the last such study in Brazil was published in 2011, referring to overall mortality trend from cancer, including prostate, from 1980 to 200617.

Considering the epidemiological relevance of prostate cancer in male morbidity and mortality, and since it shows good prognosis when detected in the early stages, on-going studies on its mortality trends should be encouraged. The current study thus aimed to analyze the distribution and time trend in mortality from prostate cancer according to the major geographic regions of Brazil. 


\section{Methods}

The study analyzed historical series of prostate cancer mortality according to age bracket, States, and major geographic regions of Brazil from 1980 to 2010. Data on deaths (the numerator in the mortality rate) were obtained from the Mortality Information System (Information Technology Department of the Brazilian Unified National Health System. http://www.datasus.gov.br), including deaths from prostate cancer classified in the $9^{\text {th }}$ and $10^{\text {th }}$ revisions of the International Classification of Diseases (ICD-9 and ICD-10) with codes 185 (from 1980 to 1995) and C61 (1996 to 2010) (Information Technology Department of the Brazilian Unified National Health System. Informações de Saúde: Demográficas e Socioeconômicas. http://www2. datasus.gov.br/DATASUS/index.php?area=0206, accessed on 14/Feb/2012). Demographic data were population estimates (the denominator in mortality rates) provided by the Brazilian Institute of Geography and Statistics (IBGE. População Residente - Brasil, 2011. http://tabnet.data sus.gov.br/cgi/tabcgi.exe?ibge/cnv/popuf.def, accessed on 06/Dec/2011) for the respective years.

In order to minimize potential bias due to differences in data quality on death certificates between States and over the years, the percentage of deaths from ill-defined causes was redistributed among other causes of death, except external causes 18 .

Deaths from ill-defined causes with codes 780-799 and R00-R99 in ICD-9 and ICD-10, respectively, were redistributed proportionally according to the methodology used by the World Health Organization (WHO) 19. This technique follows proportional redistribution by which coded deaths occur in each of the chapters of ICD-9 and ICD-10 among deaths from defined causes, except for external causes, and has been used in other Brazilian studies 18. Correction factors were calculated according to the following formula: correction factor $=$ total deaths - deaths from external causes/total deaths - deaths from external causes - deaths from ill-defined causes.

To avoid overestimating the number of deaths from prostate cancer, we distributed 50\% of the ill-defined causes as corresponding to neoplasms in each age bracket and State. This criterion was based on Mello-Jorge et al. 20 for validation of ill-defined causes of death.

Deaths corrected by State and age bracket were totaled to comprise the data by major geographic region and Brazil as a whole. Mortality rates were calculated and standardized with and without correction, by age, using the direct meth- od, taking the standard world population as the reference 21 . Time trend analyses were performed according to major geographic regions (CentralWest, Northeast, North, Southeast, South) and age brackets (40-59, 60-69, 70-79, $\geq 80$ years), and by State.

Time trend analysis used Prais-Winsten generalized linear regression 22, which allowed correction of first order autocorrelation in the analysis of data organized over time. It was thus possible to interpret whether the mortality trends were increasing, decreasing, or stable, besides quantifying the mean annual mortality increment with the respective $95 \%$ confidence intervals (95\%CI). Statistical analysis used Stata version 9 (Stata Corp., College Station, USA).

To improve the visual grasp in the graphic display of time trends, third order moving average smoothing was used 22 .

\section{Results}

From 1980 to 2010 there were 196,550 deaths from prostate cancer in Brazil, $49.7 \%$ in the Southeast region of the country and $20.6 \%$ in the Northeast. Redistribution of deaths from ill-defined causes led to a $7.7 \%$ increase, totaling 211,654 deaths. Standardized mortality rates increased from 9.9 (unadjusted) to 10.8 deaths per 100,000 men after correction, for the period's overall average. Risk of death from prostate cancer in Brazil increased from 6.6 in 1980 to 14.2 deaths per 100,000 men in 2010 (corrected rates) (Figure 1).

There was an upward trend in the mortality rate from prostate cancer in all major geographic regions of the country. The mortality rate in the Northeast increased from 3.8 in 1980 to 14.3 deaths/100,000 men in 2010. In the South, the rate increased from 7.8 to 15.1 deaths, and in the Southeast from 6.9 to 14.3 deaths/100,000 men (Figure 2).

Table 1 shows the mean variation in mortality rates according to the major geographic regions and the country as a whole, and the respective prostate cancer mortality trends. The Northeast showed the highest mean annual variation with $5 \%$, while the lowest rates were in the South and Southeast, with mean annual increases of $2.4 \%$ and $2.6 \%$, respectively. Although the risk of death increased in all the regions, the upward trend was smaller in the South and Southeast.

The highest mortality rates from 1980 to 2005 occurred in the South and Southeast. For 18 and 10 years, respectively, the States of Rio Grande do Sul and Rio de Janeiro maintained the highest mortality rates, although with downward time trends (data not shown). 
Figure 1

Historical series of mortality rates * from prostate cancer according to major geographic regions of Brazil from 1980 to 2010

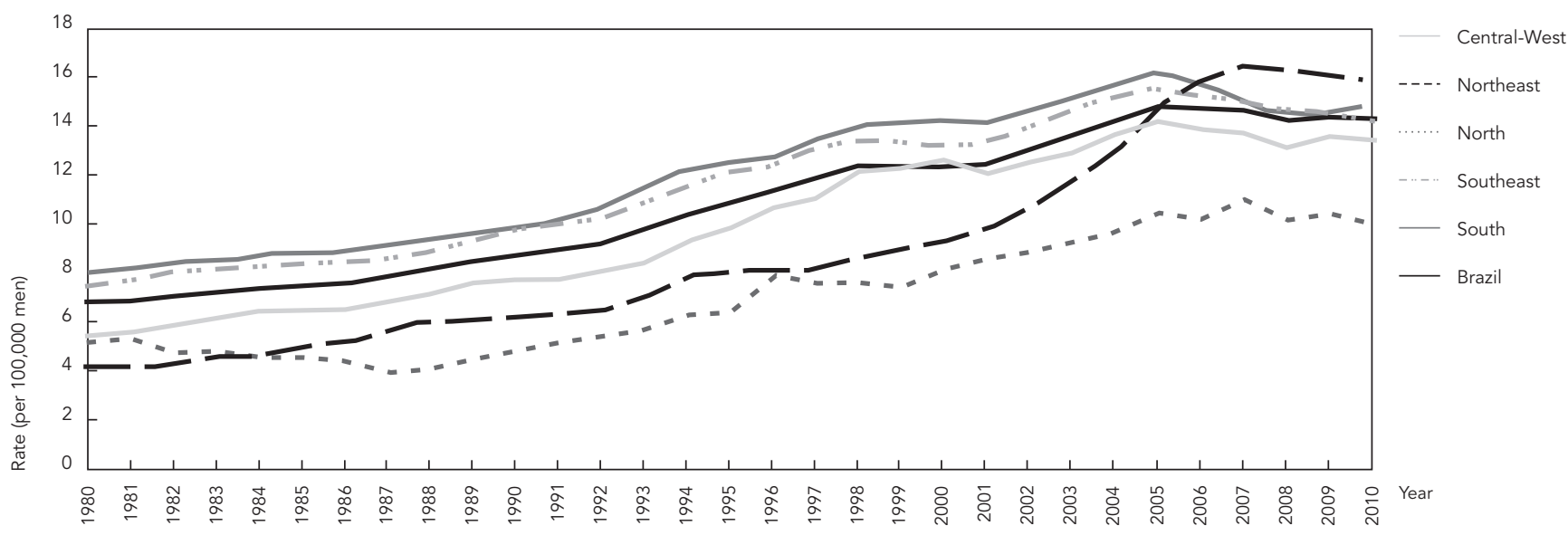

* Corrected and standardized by world population age bracket and smoothed graph.

Figure 2

Prostate cancer mortality rate, uncorrected and corrected, in Brazil from 1980 to 2010.

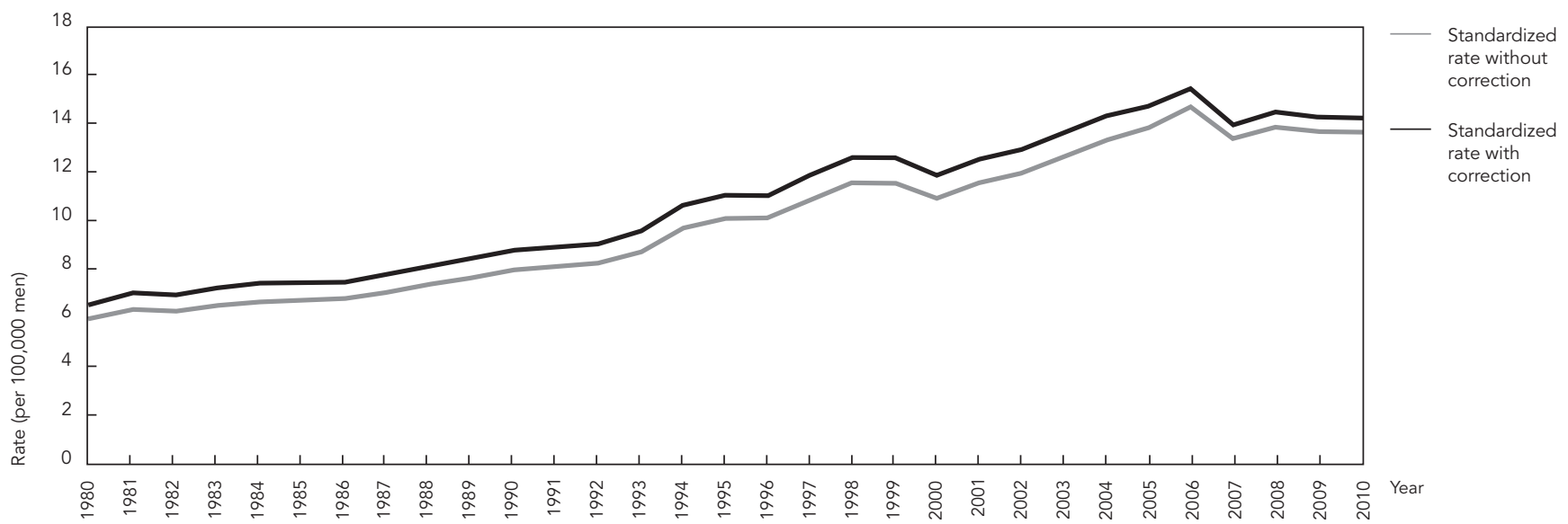

The North showed the lowest rates from 1983 (3.7 deaths per 100,000 men) to 2010 (10.1 deaths per 100,000 men) (data not shown).

Table 2 shows the trends in mortality rates in the five geographic regions according to the age bracket. The 70-and-older bracket concentrated $41.4 \%$ of the deaths in the country. Of the total deaths, $6.5 \%$ occurred below 60 years of age.
Younger men (40 to 59 years of age) showed a stable mortality trend in the Central-West and South and an upward trend in the other regions. Comparing the 40-59 and 60-69-year age brackets, the risk of dying increased 13 times in the country (from 3.0 to 39.7 deaths per 100 thousand men). Mean variation in mortality rates was significantly higher in the Northeast compared 
Table 1

Prostate cancer mortality trend, total corrected deaths, mean variation (\% and $95 \%$ confidence interval $-95 \% \mathrm{Cl}$ ), according

to major geographic regions of Brazil, 1980 to 2010.

\begin{tabular}{lccccc}
\hline \multirow{2}{*}{ Regions } & Corrected deaths & Mean variation (\%) & \multicolumn{2}{c}{$95 \% \mathrm{Cl}$} & Interpretation \\
& & & Lower & Upper & \\
\hline Central-West & 12,189 & 3.5 & 2.9 & 4.1 & Upward \\
Northeast & 47,055 & 5.0 & 4.5 & $\mathbf{5 . 5}$ & Upward \\
North & 7,592 & 3.5 & 2.6 & 4.4 & Upward \\
Southeast & 105,089 & 2.6 & 2.0 & 3.2 & Upward \\
South & 39,730 & 2.4 & 1.8 & 3.1 & Upward \\
Brazil & 211,654 & 2.8 & 2.2 & 2.4 & Upward \\
\hline
\end{tabular}

Table 2

Prostate cancer mortality trend and mean variation (\% and $95 \%$ confidence interval $-95 \% \mathrm{Cl}$ ) according to age brackets and major geographic regions of Brazil, 1980 to 2010 .

\begin{tabular}{lcccccccc}
\hline Regions & \multicolumn{4}{c}{ Mean variation $[\%(95 \% \mathrm{Cl})]$} & & \multicolumn{2}{c}{ Interpretation } \\
& $\mathbf{4 0 - 5 9}$ & $\mathbf{6 0 - 6 9}$ & $\mathbf{7 0 - 7 9}$ & $\geq \mathbf{8 0}$ & $\mathbf{4 0 - 5 9}$ & $\mathbf{6 0 - 6 9}$ & $\mathbf{7 0 - 7 9}$ & $\geq \mathbf{8 0}$ \\
\hline Central-West & $1.4(-0.1 ; 2.9)$ & $2.4(1.8 ; 3.1)$ & $\mathbf{2 . 4}(1.8 ; 3.0)$ & $3.2(2.2 ; 4.2)$ & Stable & Upward & Upward & Upward \\
Northeast & $2.1(1.6 ; 2.6)$ & $\mathbf{3 . 6}(2.9 ; 4.3)$ & $4.2(3.5 ; 4.9)$ & $5.5(4.6 ; 6.5)$ & Upward & Upward & Upward & Upward \\
North & $1.5(0.1 ; 2.9)$ & $2.5(2.0 ; 3.0)$ & $3.1(2.8 ; 3.5)$ & $3.0(1.9 ; 4.0)$ & Upward & Upward & Upward & Upward \\
Southeast & $0.9(0.2 ; 1.6)$ & $0.9(-0.1 ; 2.0)$ & $0.9(-0.2 ; 2.0)$ & $1.9(0.9 ; 2.9)$ & Upward & Stable & Stable & Upward \\
South & $0.6(-0.2 ; 1.4)$ & $0.9(0.0 ; 1.9)$ & $1.6(1.0 ; 2.3)$ & $2.4(1.4 ; 3.3)$ & Stable & Upward & Upward & Upward \\
Brazil & $1.1(0.5 ; 1.7)$ & $1.5(0.5 ; 2.4)$ & $1.9(1.2 ; 2.6)$ & $2.9(2.3 ; 3.5)$ & Upward & Upward & Upward & Upward \\
\hline
\end{tabular}

to the other regions of Brazil, in all age brackets (Table 2).

\section{Discussion}

The study found an increase in mortality rates from prostate cancer in all regions of Brazil from 1980 to 2010. The highest rates occurred in the South and Southeast. However, in the North and Northeast the mean annual increase was higher in the three decades.

International time trend studies on mortality rates from prostate cancer identified decreases in England 23, France, Australia, United States 24, Singapore 25, Nordic countries 26, Austria 27, and Norway ${ }^{28}$. Explanations for the downward trends in different countries suggest multiple factors, including changes in treatment strategies 24,28.

As in Brazil, countries like Russia, Japan, 24 and Poland ${ }^{29}$ presented upward mortality trends, suggesting natural aging 24 of the population as the principal trigger in cell alterations.

In the 1990s, the increase in prostate cancer incidence in all the Nordic countries except Denmark led to the suspicion that the mortality trend was overestimated. Older patients may have had prostate cancer recorded as their cause of death, while other causes such as heart failure and lung diseases may have been the real underlying causes of death 30 .

A study that compared mortality from prostate cancer in the United States and the United Kingdom showed that differences in treatment can help explain differences in mortality trends between countries. In the United States, prostate cancer patients receive more aggressive treatment for the disease (radical prostatectomy) compared to the United Kingdom, where the mortality trend is higher. The drop in mortality in the United States may also be favored by the large number of trials involving new therapeutic 
approaches (Information Technology Department of the Brazilian Unified National Health System. IDB 2010 Brasil: Indicadores de Mortalidade, 2010. http://tabnet.datasus.gov.br/ cgi/tabcgi.exe?idb2010/c05.def, accessed on 04/ Sep/2012).

In Brazil, PSA tests paid for by the Brazilian Unified National Health System increased by $573.3 \%$ (from 34,157 to 195,825 ) from 1999 to 2007 , with no indication of population and opportunistic screening by the Ministry of Health. The Southeast region supplied the most test, especially in the States of São Paulo and Minas Gerais $(31.7 \%$ and $15 \%) 31$, which may have contributed to an increase in prostate cancer diagnosis. There was a $32.9 \%$ increase in diagnostic and therapeutic services from 2005 to 2009 . From the regional perspective, the largest increases in services occurred in the Northeast $(50.7 \%)$ and North (35\%) and the lowest in the Central-West (15.2\%) 32 . However, the expansion of testing in the country had no impact in terms of a reduction in mortality.

The reduction in deaths from ill-defined causes and thus improvement in classification of causes of mortality for diseases in general in the Northeast and North can also be explained by the implementation of specific programs and actions at the Federal, State, and Municipal levels. In Brazil, the proportion of deaths from ill-defined causes decreased from $20 \%$ in 1980 to $7.2 \%$ in 2009 , when it varied from $3.8 \%$ in the Central West to $7.7 \%$ in the Northeast 33 .

The increasing mortality rates in all States of the Northeast are also consistent with a study from 1996 to 2005, focusing on uterine cervical cancer 34. Improved access to diagnostic tests in the interior, leading to an increase in case detection, help explain this situation. Meanwhile, a study in Corumbá, Mato Grosso do Sul State 35, identified a downward trend in prostate cancer mortality, suggesting that improved diagnosis and treatment accounts for the drop in death from prostate cancer, corroborating other studies $23,24,25,26,27$. According to a study from 1980 to 2006 , the increase in mortality rate was common to all the State capital cities in the major geographic regions, except the South of Brazil, where rates were higher in the countryside 16 . According to the current study, the South and Southeast, Brazil's wealthiest regions, showed the lowest mean annual increases, below average for the country. Quality of care, training in diagnosis and treatment, quality of information provided to patients, and increased survival for patients with a cancer diagnosis may have contributed to the differences in relation to the other regions of the country 36 .
Analysis of mortality rates from prostate cancer by age bracket showed an upward trend in most of the regions. The exceptions, with stable mortality rates, included the Southeast (60 to 79 years of age) and Central-West and South (40 to 59 years), presumably due to intensification of early treatment, considering the increasing supply of radiotherapy services in these regions 17 . Upward trends in the other regions at ages above 70 years corroborated the study by Fonseca et al. 14, which included prostate cancer in Brazilian State capitals.

Argentina showed an upward annual trend in prostate cancer mortality rates from 1986 to 1998 in age brackets 55 to 64 years (1.3\%), 65 to 74 (3.6\%), and 75 and older (4.4\%), with a drop in subsequent years. The increase in deaths in older age brackets confirmed the striking effect of age, or the relationship between aging and mortality. The lower risk in younger age groups in this study suggests the influence of healthier behavioral factors 37 .

The current study showed a significant upward trend in the mortality rate in the 40 to 59-year age bracket, except in the Central-West and South of Brazil. In England and Wales, the mortality rate from prostate cancer declined by $26 \%$ from 1992 to 2004 in the 55 to 74 -year age bracket. The findings suggest greater use of radical prostatectomy to treat localized tumors, contributing to a reduction in long-term mortality trends. In Brazil, there is still a gap in research on the association between the increase in deaths in the younger age bracket and family history 10 .

Potential limitations to this study include the inability to disaggregate State mortality rates between the capital and the interior, in addition to the fact that the correction of deaths did not contemplate the imputation of unrecorded ages. However, in this study only 267 deaths $(0.14 \%)$ presented unknown age.

The study increased the visibility and updated the situation with prostate cancer mortality in Brazil and its major geographic regions. However, strategies are still needed to improve control measures for prostate cancer. The study highlights the importance of on-going improvement in data from information systems, indispensable for monitoring diseases. 


\section{Resumen}

Se analiza la distribución y la tendencia temporal de la mortalidad por cáncer de próstata según macrorregiones, Unidades Federativas (UF) y franja etaria en Brasil. Fueron utilizados datos del Sistema de Información sobre Mortalidad (SIM), con los óbitos acaecidos entre 1980 y 2010. Se estimó la tendencia de mortalidad por el método de Prais-Winsten de regresión lineal generalizado. Se verificó una tendencia temporal ascendente en la tasa de mortalidad en todas las regiones del país, con un aumento medio de un 2,8\% al año. La tendencia ascendente en la tasa de mortalidad se produjo en la mayoría de las franjas de edad, concentrándose los óbitos entre hombres de 70 a 79 años (41\%) y un aumento significativo entre 40 y 60 años. Hubo un aumento significativo en la tasa de mortalidad de la Región Nordeste, y en las 25 UF en todas las franjas de edad, comparadas con las demás regiones de Brasil. Se verificó la importancia en la redistribución de óbitos por causas mal definidas para la corrección de las tasas de mortalidad. Los resultados apuntan diferencias significativas regionales y la necesidad de un monitoreo continuo de la mortalidad por cáncer de próstata en Brasil.

Neoplasias de la Próstata; Mortalidad; Salud del Hombre

\section{Contributors}

M. B. M. Conceição participated in the conception, elaboration, analysis, writing, interpretation, and final approval. A. F. Boing contributed to the elaboration of the database and revision of the intellectual content. K. G. Peres contributed to the project's conception, analysis, writing, relevant critical revision of the intellectual content, and final approval.

\section{References}

1. Ferlay J, Shin HR, Forman D, Mathers CD, Parkin D. Globocan 2008: cancer incidence and mortality worldwide. Lyon: International Agency for Research on Cancer; 2010.

2. Instituto Nacional de Câncer. Estimativa 2012: incidência de câncer no Brasil. Rio de Janeiro: Instituto Nacional de Câncer; 2011.

3. Instituto Nacional de Câncer. Câncer de próstata: consenso. Rio de Janeiro: Instituto Nacional de Câncer; 2002.

4. Malta DC, Morais Neto OL, Silva Junior JB. Apresentação do plano de ações estratégicas para o enfrentamento das doenças crônicas não transmissíveis no Brasil, 2011-2022. Epidemiol Serv Saúde 2011; 20:425-38.

5. Stokes ME, Ishak J, Proskorovsky I, Black LK, Huang Y. Lifetime economic burden of prostate cancer. BMC Health Serv Res 2011; 11:349.

6. Rhoden EL, Averbeck MA. Câncer de próstata localizado. Rev AMRIGS 2010; 54:92-9.

7. National Cancer Institute, Surveillance Epidemiology and End Results. Fast stats: an interactive tool for access to SEER cancer statistics. http://seer.cancer.gov/csr/1975_2009_pops09/results_merged/ sect_23_prostate.pdf (accessed on 30/Nov/2012).
8. Leitzmann MF, Rohrmann S. Risk factors for the onset of prostatic cancer: age, location, and behavioral correlates. Clin Epidemiol 2012; 4:1-11.

9. Tortajada JF, Castell JG, Tornero OB, Garcia JAO. Factores de riesgo constitucionales en el cáncer de próstata. Actas Urol Esp 2011; 35:282-8.

10. Hussain S, Gunnell D, Donovan J, McPhail S, Hamdy F, Neal D, et al. Secular trends in prostate cancer mortality, incidence and treatment: England and Wales, 1975-2004. BJU Int 2008; 101:547-55.

11. Garnick MB. The great prostate cancer debate. Sci Am 2012; 306:38-43.

12. Chou R, Croswell JM, Dana T, Bougatoss C, Blazina I, Fu R, et al. Screening for prostate cancer: a review of evidence for the U.S. preventive services task force. Ann Intern Med 2011; 155:762-71.

13. Boing AF, Vargas SAL, Boing AC. A carga das neoplasias no Brasil: mortalidade e morbidade hospitalar entre 2002-2004. Rev Assoc Med Bras 2007; 53:317-22.

14. Fonseca LAM, Eluf Neto J, Wünsch Filho V. Tendências de mortalidade por câncer nas capitais dos estados do Brasil, 1980-2004. Rev Assoc Med Bras 2010; 56:309-12. 
15. Wünsch Filho V, Moncau JE. Mortalidade por câncer no Brasil 1980-1995: padrões regionais e tendências temporais. Rev Assoc Med Bras 2002; 48:250-7.

16. Oliveira Jr. FJM, Cesse EAP. Morbi-mortalidade do câncer na cidade do Recife na década de 90. Rev Bras Cancerol 2005; 51:201-8.

17. Silva GA, Gamarra CJ, Girianelli VR, Valente JG. Tendência da mortalidade por câncer nas capitais e interior do Brasil entre 1980 e 2006. Rev Saúde Pública 2011; 45:1009-18.

18. Gamarra CJ, Valente JG, Silva GA. Correção da magnitude da mortalidade por câncer do colo do útero no Brasil, 1996-2005. Rev Saúde Pública 2010; 44:629-38.

19. Mathers CD, Bernard C, Iburg KM, Inoue M, Fat DM, Shibuya K, et al. Global burden of disease in 2002: data sources, methods and results. Geneva: World Health Organization; 2003. (Global Programme on Evidence for Health Policy Discussion Paper, 54).

20. Mello-Jorge MHP, Gotlieb SLD, Laurenti R. O sistema de informações sobre mortalidade: problemas e propostas para o enfrentamento. I. Mortes por causas naturais. Rev Bras Epidemiol 2002; 5:197-211.

21. Segi M. Cancer mortality for selected sites in 24 countries (1950-57). Sendai: Tohoku University; 1960.

22. Kirkpatrick RC, Kirkpatrick RC, Gaynor PE. Introduction to time-series modeling and forecasting in business and economics. New York: McGraw-Hill; 1994.

23. Duncan ME, Goldacre MJ. Mortality trends for benign prostatic hyperplasia and prostate cancer in English populations 1979-2006. BJU Int 2011; 107:40-5.

24. Schröeder FH. Prostate cancer around the world: an overview. Urol Oncol 2010; 28:663-7.

25. Lim GH, Chow KY, Lee HP. Singapore cancer trends in the last decade. Singapore Med J 2012; 53:3-9.

26. Meyer MS, Mucci LA, Andersson SO, Andrén O, Johansson JE, Tretli S, et al. Homogeneous prostate cancer mortality in Nordic countries over four decades. Eur Urol 2010; 58:427-32.

27. Oberaigner W, Siebert U, Horninger W, Klocker H, Bektic J, Schäfer G, et al. Prostate specific antigen testing in Tyrol, Austria: prostate cancer mortality reduction was supported by an update with mortality data up to 2008. Int J Public Health 2012; 57:57-62.
28. Kvåle R, Møller B, Angelsen A, Dahl O, Fosså SD, Halvorsen OJ, et al. Regional trends in prostate cancer incidence, treatment with curative intent and mortality in Norway 1980-2007. Cancer Epidemiol 2010; 34:359-67.

29. Damber JE, Aus G. Prostate cancer. Lancet 2008; 371:1710-21.

30. Collin SM, Martin RM, Metcalfe C, Gunnell D, Albertsen PC, Neal D, et al. Prostate-cancer mortality in the USA and UK in 1975-2004: an ecological study. Lancet Oncol 2008; 9:445-52.

31. Instituto Brasileiro de Geografia e Estatística. Estatísticas de saúde: assistência médico-sanitária 2009. Rio de Janeiro: Instituto Brasileiro de Geografia e Estatística; 2010.

32. Instituto Brasileiro de Geografia e Estatística. Indicadores sociodemográficos e de saúde no Brasil: 2009. Rio de Janeiro: Instituto Brasileiro de Geografia e Estatística; 2009

33. Gamarra CJ, Valente JG, Silva GA. Magnitude da mortalidade por câncer do colo do útero na Região Nordeste do Brasil e fatores socioeconômicos. Rev Panam Salud Pública 2010; 28:100-6.

34. Silva JFS, Mattos IE. Padrão de distribuição do câncer em cidade da zona de fronteira: tendência de mortalidade por câncer em Corumbá, Mato Grosso do Sul, no período 1980-2006. Epidemiol Serv Saúde 2011; 20:65-74.

35. Cervi A, Hermsdorff HHM, Ribeiro RCL. Tendência da mortalidade por doenças neoplásicas em 10 capitais brasileiras, de 1980 a 2000. Rev Bras Epidemiol 2005; 8:407-18.

36. Niclis C, Pou SA, Bengió RH, Osella AR, Díaz MP. Prostate cancer mortality trends in Argentina 1986-2006: an age-period-cohort and joinpoint analysis. Cad Saúde Pública 2011; 27:123-30.

37. Riimäki M, Thomsen H, Brandt A, Sundquist J, Hemminki K. What do prostate cancer patients die of? Oncologist 2011; 16:175-81.

Submitted on 16/Jan/2013

Final version resubmitted on $24 / \mathrm{Jul} / 2013$

Approved on 22/Aug/2013 